\title{
The HIV nef protein within ARL is genetically and structurally distinct from those in the brain of patients with HAD
}

\author{
Susanna L Lamers ${ }^{1 *}$, Gary B Fogel ${ }^{2}$, Leanne Huysentruyt ${ }^{3}$, Art Poon ${ }^{4}$, Michael S McGrath ${ }^{3}$ \\ From $12^{\text {th }}$ International Conference on Malignancies in AIDS and Other Acquired Immunodeficiencies \\ (ICMAOI) \\ Bethesda, MD, USA. 26-27 April, 2010
}

\section{Background}

Despite antiretroviral therapy, macrophages remain significant cellular reservoirs for HIV infection. Two fatal macrophage-mediated diseases still occur at a much higher rate in the HIV-infected and HAART-treated population: (1) AIDS-related lymphoma (ARL), a noninflammatory disease, and (2) HIV-associated dementia (HAD), an inflammatory disease. The frequency of HIVinfected macrophages in ARL is $50 \%$. Macrophages are the primary HIV-infected cells in the brain. The mechanisms that lead to the development of these diseases are not understood. Because certain subtypes of HIV are associated with a higher prevalence of HAD, a viral genetic determinant for HAD development is likely. On the other hand, ARL development occurs fairly consistently across multiple HIV subtypes and genetic analysis has clearly differentiated ARL tissue-associated HIV from non-ARL tissue HIV within individuals. These facts raise two questions: (1) Are there tumor-specific genetic differences among HIV proteins that could influence the macrophage to accelerate ARL development? (2) How might HAD-associated and ARL-associated viruses differ at the genetic and structural levels? Our goal was to analyze HAD and ARL viral sequences and determine whether a disease association could be identified within viral proteins.

\section{Methods}

The AIDS and Cancer Specimen Resource (ACSR) archives tissue samples derived from well-documented cases of both ARL and HAD. Multisite autopsies of 7

\footnotetext{
${ }^{*}$ Correspondence: susanna@hivanalysis.net

'BiolnfoExperts, Thibodaux, LA, USA

Full list of author information is available at the end of the article
}

patients with ARL, HAD, and other neurological and systemic disorders were identified at the ACSR. More than 20 sequences from each of 5 to 7 tissues from each patient were sequenced. The HIV nef sequence was used in multiple genetic analyses, including a neural net signature pattern analysis, a tertiary structural analysis, and an analysis of the stability of an HIV viral microRNA associated with apoptosis.

\section{Results}

Signature pattern analysis clearly separated ARL from HAD viruses and identified positions that may in concert produce specific pathological outcomes. HIV subtype $\mathrm{D}$ viruses are known to be associated with a high rate of HAD. Comparative tertiary structural analysis of nef showed that HAD viruses were more similar to HIV subtype $D$ viruses than ARL viruses. ARL viruses were either missing or possessed a less stable miR-H1 structure compared to HAD viruses.

\section{Conclusions}

Our results show that HIV-associated diseases are likely related to specific viral genetic signatures and structures. Discovery of an ARL virus would enable the development of diagnostic tools and identify subsets of viruses to be targeted with drugs or vaccines.

\footnotetext{
Acknowledgements

This article has been published as part of Infectious Agents and Cancer Volume 5 Supplement 1, 2010: Proceedings of the $12^{\text {th }}$ International Conference on Malignancies in AIDS and Other Acquired

Immunodeficiencies (ICMAOI). The full contents of the supplement are
} available online at http://www.biomedcentral.com/1750-9378/5?issue=S1. 


\section{Author details}

'BiolnfoExperts, Thibodaux, LA, USA. ${ }^{2}$ Natural Selection Incorporated,

San Diego, CA, USA. ${ }^{3}$ Department of Medicine, University of California, San Francisco, San Francisco, CA, USA. ${ }^{4}$ British Columbia Centre for Excellence in HIV/AIDS, Vancouver, British Columbia, Canada.

Published: 11 October 2010

doi:10.1186/1750-9378-5-S1-A77

Cite this article as: Lamers et al:: The HIV nef protein within ARL is

genetically and structurally distinct from those in the brain of patients

with HAD. Infectious Agents and Cancer 2010 5(Suppl 1):A77.

Submit your next manuscript to BioMed Central and take full advantage of:

- Convenient online submission

- Thorough peer review

- No space constraints or color figure charges

- Immediate publication on acceptance

- Inclusion in PubMed, CAS, Scopus and Google Scholar

- Research which is freely available for redistribution

Submit your manuscript at www.biomedcentral.com/submit
C Biomed Central 